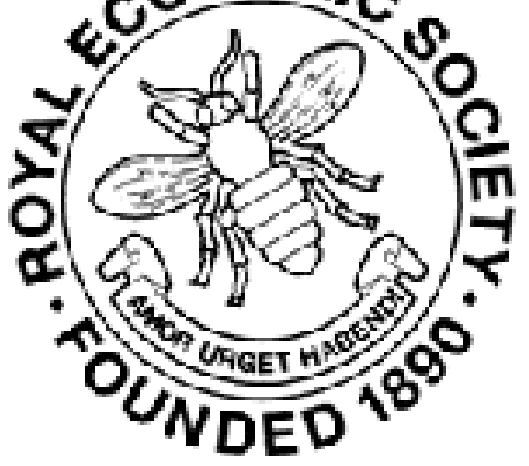

\title{
WILEY
}

The Problem of Housing Author(s): William Smart

Source: The Economic Journal, Vol. 14, No. 56 (Dec., 1904), pp. 527-540

Published by: Wiley on behalf of the Royal Economic Society

Stable URL: http://www.jstor.org/stable/2221241

Accessed: 13-06-2016 06:32 UTC

Your use of the JSTOR archive indicates your acceptance of the Terms \& Conditions of Use, available at

http://about.jstor.org/terms

JSTOR is a not-for-profit service that helps scholars, researchers, and students discover, use, and build upon a wide range of content in a trusted digital archive. We use information technology and tools to increase productivity and facilitate new forms of scholarship. For more information about JSTOR, please contact support@jstor.org.

Royal Economic Society, Wiley are collaborating with JSTOR to digitize, preserve and extend access to The Economic Journal 


\section{THE PROBLEM OF HOUSING ${ }^{1}$}

For the last two years I have been continuously engaged, as a Commissioner, in studying the phenomena of the Housing of the Poor, and the problems which arise therefrom, as presented in the evidence laid before the Glasgow Municipal Commission. It is, perhaps, appropriate that I should draw upon the experience thus gained for the substance of my address to-day.

The problem of housing in Glasgow is, in broad outline, very much the problem of all large centres of population and industry. The city grew up, without a plan, in days when the laws of public health were little understood or cared for; when there was little municipal control and little thought for the municipal future. It has now to undo its mistakes.

Fifty years ago people had not, I think, a very keen sense of smell ; certainly they did not associate bad smells with danger to health. They did not regard the darkness of the narrow street and the narrow window as objectionable. If I may trust my early recollections, as one who has lived in Glasgow from childhood, they associated smoke too much with their bread and butter to dream of grumbling at it. They were rather afraid of cold water, and baths were almost unknown. Perhaps they were fonder of each other's society than we are; at any rate, they rather preferred to live as many as possible in one room and sleep three in a bed.

When the city came to its senses, about forty years ago, and realised what an Augean stable there was to clear out, it turned to the work with a will. Considering the still unformed state of public opinion, the City Improvement Act of 1866 was a very drastic one. It scheduled whole areas of slums and pulled them

1 Presidential Address to the Economic Science and Statistics Section of the British Association, 1904. 
down, dishousing, within five years, some 19,000 persons; rating for deficits to the amount of some $£ 600,000$ altogether; and the burden was borne without much demur. By the time the Act had done its work, the public mind had become thoroughly awake to the danger of letting things alone. Further powers were asked and obtained for closing, demolition, and rebuilding. Four years ago was passed the Building Regulations Act, which, in addition to regulating the construction of new houses, made the provision of sufficient air and light space in front of the bedroom windows compulsory, and this was so far retrospective that over 4,000 houses, conforming to sanitary requirements in other respects, became on a certain date "illegal houses" simply from the fact that they had not the sufficient space outside.

These measures did not pass without criticism, but generally it was recognised that they were demanded in the interests of public health. When, however, it was realised that dishousing on this large scale was accepted by a very large section of the municipality as logically calling for municipal housing on a similarly large scale, public attention was roused. It began to come home to the citizens that very gigantic operations were being carried out, and very gigantic responsibilities for the future being incurred, without, as it seemed, any thorough diagnosis or any definite plan. The whole problem was seen to be one which, in other circumstances, would have called for a Royal Commission. The demand was made for a local inquiry on similar lines; and, when the Prime Minister gave his cordial approval to such an inquiry, the municipality appointed a mixed Commission of nine councillors and six private citizens, with a remit to examine (a) the causes which led to congested and insanitary areas and overcrowding; $(b)$ the remedies which could, or should, be adopted for the clearance of existing congested, insanitary, and overcrowded areas, and for the prevention of these evils in future; and (c) any other phases of or questions connected with the housing problem in Glasgow which the Commission may deem it desirable, necessary, or expedient to consider and report upon.

The evidence, report, and recommendations are now before the public. $^{1}$ Generally speaking, they bear out the conclusion that many things hitherto discussed as parts of the Housing Problem are not problems at all, but phenomena which merely need to be known to secure their abolition. Slums must be cleared away; streets must be widened; overcrowding must be prevented; the liberty of the landlord to sell and of the tenant to use insanitary

${ }^{1}$ William Hodge \& Co., Glasgow. 
houses must be interfered with; light and air space must be guarded as a right of the poor. These are dictates of public health and public morals, and the Commission calls for the firm administration of powers which the municipality already has, and for further powers where these are not sufficient.

Connected incidentally with this there are, indeed, minor problems, such as questions of procedure, of acquisition, of compensation, and the like; but, so far as I am able to judge, the real Housing Problem of to-day narrows itself down to this: how far the experience gained points in the direction of the municipality itself building and owning houses for certain of the poorer classes.

To this the Commission has contributed an answer in so far that, in the special circumstances of Glasgow, it recommends a limited scheme of municipal building and owning. But it adds the words "without expressing any opinion upon the general policy of municipal housing."

I venture to think that there is no more pressing duty now incumbent on economists than to take up this general question. I propose, then, first, to consider building and owning of house property as a branch of municipal activity; and, second, to examine the particular circumstances which suggest a revision or relaxation of general principles.

For a municipality, deliberately and of set intention, to add a new competitive industry to its already manifold activities, is a serious matter from three points of view.

(1) House-owning is a business, and it is neither a routine business nor one where success is certain. So far as it has not a monopoly, a municipality cannot presume upon demand-it cannot be sure of a remunerative sale for the goods it provides. As a builder, it has advantages and it has disadvantages; as an owner, it has also advantages and disadvantages-particularly, perhaps, in that it has a conscience.

Assuming, however, that a municipality can manage its enterprises as well as private citizens manage theirs, and that its houseowning covers all recognised expenses and runs no risk of coming upon the rates, what must be emphasised is that it pledges the future ratepayers for the security of all the capital borrowed. It is short-sighted to conceal the dangers and responsibilities of this by calling such a debt " productive." Borrowed capital changed into stone and lime certainly remains an "asset," but whether the asset is worth much, or little, or nothing, depends on the value which future generations will put upon it. An old mill may be 
"good" for half a century more as a building, and yet be worth less than nothing as a mill. So may a tenement of houses, by change of circumstances, lose its rent-producing capacity and call only for demolition, long before it has suffered much deterioration as a building. In such circumstances the ideal kind of house would be one constructed to last, say, thirty years at the outside. But this, of course, is the last thing that municipalities in their present mood would think of doing, and they generally make it impossible by their own building regulations. Besides this, there is the consequence of the "economic trespass"; that dwellinghouses for the poor generally take up the space of buildings of a more remunerative character, and so keep down the rateable value of the area, while increasing its expenses.

(2) It enters into direct competition with many of its own ratepayers, competing not only with the comparatively small class of builders, but with the great class of owners of house property. Apart from the equity of this, which is too large a question to enter on here, the results may be very serious. Free competition of producers to serve the public is, of course, a good thing, and in nothing, perhaps, is it more desirable than in the purveying of houses, where the length of time required for erection tends to some extent towards monopoly. But competition is good because, and to the extent that, it keeps down prices by increasing supply, and the action of a municipality, working with money borrowed at a gilt-edged security rate, is very likely to have the opposite effect; it may result in a positive diminution of the total supply of houses, and so a rise of rent, by reason of the discouragement given to private builders through the appearance of a rival with w.hom they cannot compete on equal terms. The monopoly which municipalities secure for their other industries prevents such a danger ; but it must be emphasised that a municipality supplying a few hundred houses, where the well-being of the citizens as a whole depends on private enterprise continuing to supply some hundreds of thousands, occupies an entirely different position from a municipality providing all the water, gas, electricity, or tramway service which the citizens may demand.

(3) By pledging the public credit for a new debt, and adding a new activity and responsibility to already overworked members of the municipality, it pro tanto prevents the expansion of municipal activity in other directions. Public functions, however admirable, must be limited by the public purse, and probably will be limited, long before that purse is exhausted, by the ratepayers' revolt against increased rates. This must not be regarded 
as special pleading against further increase of municipal duties and expenses. Anyone who studies the growing complexity of city life and its growing requirements of inspection, control, and administration generally, to say nothing of possible municipal expansion in other industrial and com: mercial directions, must be impressed by the necessity and magnitude of the tasks that lie before public bodies in the future, and must recognise the inexpediency of taking on any new burden without the most serious consideration. He will at least ask that the cost be counted and definite limits laid down. And these limits, in the present case, are not easily laid down. To mention only one thing; it would be exceedingly difficult, on grounds of equity, to justify the giving of an advantage to one class and refusing it to another, and, when that was done, to establish courts and criteria which should define and limit the class favoured. But unless such definitions and limitations were attempted, the municipality would be embarked on an expenditure of which no one could see the end.

These are considerations against municipal building and owning derived from the general principles' which should, in my opinion, regulate all municipal expansion. They are not, of course, decisive against it. But they suggest that very definite and weighty reasons must be put forward on the other side.

It will be admitted that the interests of public health, public morals, and industrial efficiency are definite and weighty reasons, and I should give the most sincere consideration to the argument of those who ask for municipal housing on such grounds. There are some respects in which the provision of houses seems to come under the natural work of a municipality almost as much as do the provisions of gas and water. The house, as the condition of the home, stands at the very centre of individual morality and health, and, as such, is a direct condition of the efficiency of labour. It is far too little realised that a sanitary and comfortable house among quiet neighbours has a "productive value," and is, quite definitely, one of the factors of wage-earning; in other words, a good house, as compared with a slum, brings with it the possibility of paying a higher rent for it. The consideration which gives strength to the argument for municipal building and owning is that municipal control over certain classes of house-control even violating the sanctity of the Englishman's castle-is necessary in these interests. We have in Glasgow 20,000 houses whose doors must open at any 
hour of the night at the knock of the sanitary inspectors. In a city every house is either a centre of good influence or of contamination, material and moral, and, the more closely houses are packed, the more definite the need of positive control and regulation. Such control obviously would be most effective in the hands of a municipality that owned the houses. In view, then, of the actual circumstances of slum life which prevail in every large city, and in view of the hopelessness of escape on the part of the low-paid wage-earner from such contagious influences, there seems prima facie a strong case for the provision of at least one and two-roomed houses by an agency which would aim primarily at affording to the tenants the conditions of health, morality, and efficiency, not only in the construction of the houses, but in their continued administration and control. I have always held that the owning of poor-class property carries with it a moral responsibility which is not escaped by the owner shutting his eyes and leaving the administration to his factor; and, on similar grounds, much might be said for a municipality owning and letting all the small houses within its area. This would at least secure a "clean city."

Such a position, then, is quite intelligible as a counsel of perfection, and it might be worth consideration in the case of a city planned, like a garden city, from the beginning. But, in the actual circumstances of our cities, I mention it merely to bring out my point. For there is no proposal before any municipality of to-day of taking over and making a monopoly of the supply of small houses, or even of building all the small houses that are needed in the future. The utmost that has been proposed is the building and letting of a limited number of such houses in direct rivalry with private builders and owners. And the question which must be answered is: On what principle, or with what view, is this limited proposal made?

If it were to afford an experiment, and an object-lesson, as was done with the happiest results in the case of the Corporation lodging-houses in Glasgow, where the rise in the standard not only swept out the old and very objectionable lodging-houses, but led to the large increase of private " models " competing successfully with the municipal ones, there would probably be nothing but approval. It seems a legitimate use of public money to make public experiments which would otherwise not be made, so long as it is recognised that experiments which fail should be given up. But if the proposal is made in the full recognition that such an experiment is not an object-lesson, inasmuch as it cannot be fol- 
lowed by private enterprise ; if the reason given for it is that a certain class of tenants cannot pay the rent which private enterprise must have if it is to continue its supply, and that the municipality, as having command of capital at a very low rate of interest, can afford to undersell the market rents without coming on the rates, the matter is put on an entirely different basis. The attractiveness of a "clean city" is one thing; the attractiveness of low rents is another.

Let us look for a moment at the principles on which certain services are set aside for the Government to perform. The great mass of the national income is produced by individuals of the community dividing their labour and selling their products to each other, competing with each other as producers to serve the whole body of themselves as consumers. But there are two great classes of services which are not left to individual competition. (1) External defence, justice, police, poor relief, \&c., are given over to the Government, the expenses being covered by taxation. The principle of payment is ability, or, more philosophically, equimarginal sacrifice, on the old Platonic principle that the best state is that which is likest the individual, and that the citizen should pay to the national housekeeping on the same scale as he pays to his own private housekeeping. (2) In addition to these, certain other services are given over to the Government, central or local ; they are made monopolies, and the products are sold at a noncompetitive price. Such are the post-office and telegraph services, and in many cases gas, water, and tramway service. It is with this second class that we are concerned here, and regarding them three points must be emphasised.

The first is that the reason why these services are reserved to Government is certainly not that they can be rendered more cheaply by Government. It is, indeed, a debatable point whether they can be rendered more cheaply; where competition is not allowed, this must remain a matter of opinion. They are always reserved for some ulterior reason of public interest-some interest which might be imperilled in the conflict of private competition.

The second is that, in such cases, the Government services are general services; they are provision, on the basis of the taxpayers' or ratepayers' security, of commodities and services used and enjoyed by the great majority of the citizens.

The third is that in these services, so far as I am aware, there is no precedent for the Government selling to one class at a cheaper rate than it sells to another, on the ground that the class in question "cannot afford it." The poorest man pays a penny

No. 56.-VOL. XIY. 
for a stamp; the richest citizen of Glasgow pays no more than a halfpenny for a car-stage.

But in the limited proposal we are now considering, what is being advocated is Government provision of a certain commodity for one class alone, and the ground taken undisguisedly is, that Government can provide this commodity more cheaply than private enterprise can, and that this particular class cannot afford more. It is not, indeed, proposed that the municipality should rent at one price to the richer and another to the poorer tenant; but it is proposed that the municipality should provide houses for one class at a rate which the other classes cannot possibly enjoy.

I do not think the problem can be understood, or its gravity estimated, till it is grasped that here the municipality-the public trustee -is asked to give consent to a new principle and precedent for spending public money. Take the argument in its concrete form in Glasgow. Owing to (a) increased accommodation and conveniences, occasioned chiefly by statutory enactment; (b) increased cost of construction through the rise in wages and in the price of material ; $(c)$ increased cost of maintenance, not only owing to the rise in wages, but owing to the frequent abuse and destruction by careless tenants of the expensive fittings which modern science demands; $(d)$ increase in landlords' taxes; $(e)$ increased value of land, especially in the centre of the city :-it seems that houses of one and two apartments are not being built to let at less than $£ 6$ and $£ 9$ respectively, as against $£ 55 s$. and $£ 810 s$. in 1891 . It is represented that there is a class of wage-earners who cannot pay these rents. It is asserted that, in virtue of its advantages, the municipality can build and let such houses at $£ 410$ s. and $£ 8$ respectively without loss, and it is concluded, without more ado, that it is bound to do so.

There are two propositions here which cannot be allowed to pass without examination : the first is, that there is a class which cannot afford the higher rent; the second, that this is a valid reason for the municipality providing them with a lower one.

(1) Somewhat to the surprise of the Commissioners, it was given in evidence that, while wages generally have risen, there are labourers in Glasgow who are not earning more than $17 s$. a week -and these not casual labourers, but able-bodied men, in regular employment, and of ordinarily steady habits. To such a class sixpence a week is undoubtedly a serious consideration, and, although one might be inclined to ask if the sixpence could not, with great advantage to themselves and their families, be taken 
off the conventional necessaries of drink and, perhaps, tobacco, the point need not be pressed. My reason for doubting if even this class " cannot afford" sixpence a week extra for a house is that one of the causes, perhaps the principal one, why such men earn only $17 s$. is that they live in conditions which lower health and efficiency, and make them inefficient and unreliable workers. I fully acknowledge that such people could not pay sixpence extra for the rent of a slum such as they are occupying, but I cannot forget the "productive value" of the modern higher rented house. It seems to me that fresh air, and quiet sleep at nights, and surroundings which would react on the character and conduct of the person on whom so much depends - the wife-might easily add far more than sixpence to the earning power of the household.

There is, unhappily, a class to whom this does not, directly at least, apply. There are thousands of workers whose wages are not $17 \mathrm{~s}$., but an average of $12 \mathrm{~s}$.- -regular workers, and workers who could not take sixpence off their liquor and tobacco, for the reason that they neither drink nor smoke. I mean women workers. And to these, I submit, a good house would have a greater " productive value " than to men, for they are more subject to the illnesses and little ailments and depression which dock their wages by hours in the day and days in the month. So far as I can see, they are outside the housing question altogether, from the fact that they could not afford an independent house even at the lowest municipal rents. They must remain in the family as subsidiary wage-earners, or club together, or lodge.

(2) But assuming the very strongest case, that there is a class of unfortunate people who absolutely cannot afford to pay sixpence a week more, I should still say that this in itself is no reason why the municipality should build. To supply them with houses under the market rate would be to introduce a new precedent and principle into Government industries which would lead us far. It would be using the credit of the entire body of the ratepayers to subsidise one small class of them; it would be, in essence, similar to the old legislation which kept down the price of bread when the harvest was bad, with its extenuation that such a measure kept down the price to everybody. It would be a rate in aid of wages. And if there is any lesson to be learned from the bitter experience of a century ago, it is that the evil of a rate-in-aid is, not so much that it punishes those who have to subscribe to it, as that it punishes those who receive it, in that it effectually prevents wages from rising. Let me enlarge on this for a moment.

The employer in towns has certain economic advantages over

o 02 
his rivals outside. He is at a centre of supply of all the agents of production and at a centre of demand for his goods. The play of competition balances these advantages by imposing on him in general the charge of higher wages--a consequence and possibility recognised by the trade union practice of fixing the standard wage slightly higher in town than in country. Unfortunately there is in all large cities a class who, from physical and mental disqualifications, from want of education and technical opportunity, and from want of organisation, are compelled to take the lowest wage which will keep them in life and moderate animal efficiency; and this class tends to be in over-supply from the fact that misfortune drains into it the failures of all the other classes. The existence of this class is a public misfortune; their low wages are not only bad of themselves, but they go to the very root of the future of labour, in that they prevent the children from getting out of the class. Rising rent, the natural effect of a large population and great business premises competing for a limited area of situation, is the healthy deterrent of the abnormal influx of such labour. For a municipality to give these unfortunate people houses sixpence a week cheaper is to allow of them accepting sixpence a week less of wage than the circumstances would otherwise force the employer to give. It is not, of course, that employers, taking advantage of the helplessness of this class, would deliberately force their wages down by sixpence. It is that, in the present highly specialised organisation of industry, unskilled labour is in less and less demand, while, from the circumstances mentioned, it tends to be in over-supply; and this surplus labour offers itself for any wage that will keep it alive. As Mr. Booth says, "the poverty of the poor is mainly the result of the competition of the very poor." To deny such a causal connection between wages and public subsidies on the ground that it is " only sixpence a week," or that "people do not come into cities because they can get cheap houses," is like refusing to believe in natural law because one cannot actually see the minute movements which constitute its operation. If, then, it becomes known that, in addition to the other attractions of a city, good houses at slum rents are assured to everyone who is poor enough, it seems to me inevitable that this will further tempt the influx of unskilled labour-and, unhappily, farm labour, skilled in its own fields, becomes unskilled when transferred to the streets and factories.

This, then, being the general argument against municipal 
building and owning of houses for the poorest classes, I go on to consider if there may not be circumstances in the evolution of a city which may justify the relaxation of the principle. Glasgow again affords an object-lesson. If the houses which are a danger to public health, as hopelessly insanitary, are pulled down; if "back lands" and obstructive buildings are demolished; if the houses which are by law pronounced "illegal," and cannot, from their structure and situation, be altered, are closed; and if the overcrowding laws are put sternly in force, something between 15,000 and 20,000 persons will be turned out, and will not be able to find houses at rents such as they were paying-for these measures will practically root out the low-rented houses in Glasgow. Many of the 15,000 or 20,000, no doubt, are well-paid wageearners, who will be the better of being forced into higher-rented houses ; many of them, again, are dissolute and drunken persons, who should be " hustled " from pillar to post till there is no room for them among honest people. But many of them, in all probability, are respectable persons who, from the causes already mentioned, have come down to the $17 \mathrm{~s}$. a week level. What are these people to do? Granted that the low-rented slum property should never have been allowed to come into existence or continue; granted that the best thing that could happen to such labourers as a class is that it should be made impossible for them to accept these low wages; still, it is a very drastic thing to take away the patient's bed in order to force him to walk.

Here I am chiefly impressed by two things. The first is that it is municipal inaction and municipal action which are responsible for the hardship.

(a) It is by no fault of their own that the people to be dispossessed are in occupation of these low-class houses. The municipality for years allowed these houses to come into and remain in existence, and, to that extent, the municipality is responsible for the low standard of life which allowed the tenants to take the low wages.

(b) It is to a great extent new municipal requirements that have made it impossible to build houses which can be let at the old rents. To mention only a few of these : each adult must have 400 feet of air space, which means larger apartments; there must be ample sanitary appliances, involving expensive plumber work; there are regulations providing for a certain thickness of walls and solidity of construction, which many builders declare quite unnecessary.

The second is that, on its way towards conferring a great public 
benefit, this municipal action is likely to inflict serious hardship on a class who are least of all able to bear it. It is a recognised principle, in the science of public finance, that the charge of any general public benefit defrayed from rates or taxes should be spread over the citizens in proportion to their ability. In the present case, we have a great beneficent measure of public health by which all the citizens will gain, and gain in quite indeterminate measure ; and, although this is not defrayed from the rates, by parity of reasoning it seems to follow that one class, and that the least able to bear the burden, should not be made to bear the heavy end of it. Granted that, by the operation of ordinary economic law, wages will ultimately rise to cover the higher rent demanded by private enterprise, and granted also that the houses at a higher rent have a "productive value" which will itself enable the tenant to pay more rent, in virtue of giving him immunity from sickness, depression, low vitality, and bad neighbours, still this operation takes time, and, till time is given for the economic forces to work, there will be great hardship.

There is, besides, an opportunist argument. There seems to be no doubt that the magistrates and responsible officials have hitherto shrunk from carrying out their powers because of the hardship that will be entailed. If this hardship can be avoided, there will remain no excuse and no reason for not proceeding rigorously with measures which otherwise might be somewhat extreme.

It is in consideration of these circumstances that the Glasgow Commission has recommended the erection by the municipality, up to the extent of certain powers possessed by them under special Acts, of tenements of one and two-apartment houses, to be reserved exclusively for respectable people of the poorest class, preference being given to those dispossessed; such houses to be situated, if possible, near to the area of dispossession, and to be under carefully selected caretakers.

It will be seen that the amount of building recommended is limited, the money which the municipality can spend under the Acts referred to being fixed and known. One would have liked, perhaps, that it should have been more rigorously limited. It would have been quite possible to take a rough census of the people dispossessed and build houses only to the number necessary to accommodate those who really suffer by the dispossession - the respectable poor at low wages. And what one would have liked, besides, was the clear laying down of the principle that this is an exceptional measure, due to an exceptional set of circumstances which can never occur again if the municipality lives up to the 
powers it has sought and obtained from Parliament. Insanitary and illegal houses should never again be allowed to come into existence. Overcrowding can now be rigorously kept in check. It will clearly be the fault of the municipality if such a problem recurs.

But, on the whole, the recommendation seems to me a wise one. It escapes the chief objection, that of tempting an influx of new unskilled labour. It does not add to the supply of cheap houses, but merely fills the gaps which municipal action has itself caused. It has not advised the drastic step of compelling a rise of wages by suddenly making it impossible for a class to live without paying higher rent-which would have been accompanied by the serious danger of driving many over the verge of subsistence-but it does not give any occasion for still further lowering wages; and there is the positive good that the houses to be provided are such as naturally make men and women better workers, commanding a gradually increasing wage.

There is, indeed, I am afraid, a "loose end" in the result of the Commission. To its subsequent regret it was confined, by the limitations of its remit, to the consideration of housing within the city boundaries, and Greater Glasgow is growing more rapidly outside these boundaries. I said that the problems of Glasgow grew up because the city refused to look forward and lay down the lines of its growth. Unhappily, that course is still forced upon it, in that it has no control over the operations of its suburbs. Everyone knows that, in the near future, Glasgow must extend its jurisdiction and responsibilities. There is too much reason to fear that, when that time comes, the city will fall heir to the same problem as it has now to face-insanitary property and illplanned districts. This is a problem of all growing cities, and, in my opinion, a most urgent one.

But this is not the whole of Glasgow's answer to its Housing Problem. The municipal houses are to be reserved for the respectable poor. What about the non-respectable-probably the majority of those who will be dispossessed? So far as I can see, the criminal and the dissolute have no claim on the community so far as regards housing. They must be "hustled" ; that is, life must be made as difficult as possible for them, till either they can find no rest for the sole of their foot among decent people, or are driven to reform. And this hustling will be done to a considerable extent when all the insanitary and illegal houses are done away with, when the Corporation houses are closed against them, and when private enterprise is assisted to get rid of them, as the 
Commission recommends, by more stringent laws against the habits of disorderly and destructive tenants, and by more summary powers of ejectment. But there are many who are neither criminal nor hopelessly dissolute, and yet cannot rise simply because they are down. They have lost their character; money cannot rent them a decent house because they have no factor's line or other guarantee that they are fit for the possession of it. It is this class, perhaps, that will be most heavily hit by the dispossession, and for them also it seems that some compensatory provision should be made by the municipality. And this seems also in the interests of the community, for, if these people are not lifted up, they will be driven down.

Hence the recommendation of the Commission that " an experiment should be made in the erection of a building or buildings for those who, while unable to show any factor's line or other certificate, are willing to submit to necessary regulations as to cleanliness, respectable living, order, and punctual payment of rent, with the view of rehabilitating their character, and in time qualifying for a better house; such houses to be of the plainest construction, with indestructible fittings, and capable of being quickly and efficiently cleansed."

It is avowedly an experiment. The diffieulty is not to provide such houses, but to get the proper people to go into them. If any social obloquy is allowed to attach to these houses, the proper people will not go into them. But it is an experiment to which I think everyone will wish God-speed. At any rate, it removes the last excuse for not going forward systematically, rigorously, and continuously with the renovation, closure, and demolition of bad houses, and with the prevention of overcrowding, which are the beginnings of any solution of the Housing Problem.

William SmarT 